\title{
Research on testing method of resin sand high temperature compressive strength
}

\author{
*Peng Wan', Luan-cai Li', Long Zhang' and Wen-qing Wang ${ }^{\mathbf{1}}$ \\ 1. State Key Laboratory of Materials Processing and Die \& Mould Technology, Huazhong University of Science \& Technology, Wuhan 430074, \\ China \\ 2. School of Metallurgical Engineering, Anhui University of Technology, Ma'anshan 243000, China
}

\begin{abstract}
High temperature compressive strength is one of the most important performances of resin sand; its value directly concerns the quality of castings. In order to seek the best testing method of resin sand high temperature compressive strength, a self-developed instrument was used to carry out experiments, and the sample shape and size were designed and studied. The results show that a hollow cylinder sample can reflect the strength difference of different resin sands better than a solid cylinder sample, and its data is stable. The experiments selected $\Phi 20 / 5 \times 30$ $\mathrm{mm}$ as the size of the hollow cylinder samples. The high temperature compressive strengths of phenol-formaldehyde resin coated sand, furan resin self-setting sand, and TEA resin sand were each tested. For the resin sand used for cast steel and cast iron, $1,000^{\circ} \mathrm{C}$ was selected as the test temperature; for the resin sand used for cast non-ferrous alloy, $800^{\circ} \mathrm{C}$ was selected as the test temperature; and for all the resin sand samples, 1 min was selected as the holding time. This testing method can truthfully reflect the high temperature performance of three kinds of resin sand; it is reproducible, and the variation coefficients of test values are under $10 \%$.
\end{abstract}

Key words: resin sand; high temperature compressive strength; hollow cylinder specimens; variation coefficient
CLC numbers: TG115.5
Document code: A
Article ID: 1672-6421(2016)05-335-07

$\mathrm{T}$ he performance of the sand mixtures can be classified into room temperature properties, thermal properties, high temperature properties and casting properties ${ }^{[1]}$. High temperature compressive strength is one of the most important performances ${ }^{[2]}$. High temperature compressive strength is the instant strength of sand mixtures measured after a certain time of heat preservation (its unit is $\mathrm{MPa}$ ). It reflects the high temperature strength properties of the sand mixture itself ${ }^{[3]}$. The standard measure method of American Foundrymen's Society (AFS) is as follows ${ }^{[4]}$ : a solid test specimen of $\Phi 28.6 \times 50.8 \mathrm{~mm}$ is selected; a minimum holding time of $12 \mathrm{~min}$ is normally needed; the specimen is loaded in compression until broken at the completion of the holding time; the maximum load is recorded as the high temperature compressive strength; an average of three to five test specimens is generally used.

\section{*Peng Wan}

Male, born 1988, doctoral candidate. Main research area: high temperature performance of resin sand.

E-mail: 382663254@qq.com

Received: 2016-01-19; Accepted: 2016-06-10
The high temperature compressive strength is widely used in green sand and sodium silicate bonded sand and other inorganic binder sands ${ }^{[5]}$. However, some problems exist when applying the high temperature strength to the resin sand.

The first problem is the heating atmosphere. The binder of resin sand is organic matter, and various physical and chemical changes happen in the process of contact with the liquid metal. Hydrocarbons will produce a reducing atmosphere which creates a big difference from the oxidizing atmosphere produced by green sand, sodium silicate sand and other inorganic binder sand ${ }^{[6]}$. Resin sand has different high temperature properties under a different atmosphere, so the instruments should maintain a reducing atmosphere so that they can reflect the performance of resin sand at high temperature.

The second problem is the sample size. The standard Chinese sample size for high temperature measurement is $\Phi 30 \times 50 \mathrm{~mm}$. This sample size is large, so it is difficult to heat it through. Therefore, the high temperature performance testing of clay sand is usually carried out after heating for a period of time to ensure that the whole is heated through: surface and interior. Therefore, a smaller sample size is needed ${ }^{[7]}$. 
The last problem is the parameters of testing, such as testing temperature and holding time. The resin sand sample may complete ablation and lose strength if the holding time is too long; and it will not be heated through if the heat preservation time is too short. So the heat preservation time is generally within $2 \mathrm{~min}^{[8]}$. The test temperature is between $600-1,000{ }^{\circ} \mathrm{C}$ because high temperature properties are the properties which are tested under casting temperature. Therefore, it is necessary to select the best sample size and testing parameters through the experiment and analysis.

\section{Determination of resin sand high temperature performance sample size}

\subsection{Experimental scheme}

In order to determine the size of the test sample, the heat passing through and the ablation of the resin sand were observed through a profile of different kinds of samples. Then, the sample size was selected through the reproducibility of the experimental data and according to whether it can reflect the strength difference of different resin sands. Because the of furan resin sand is black, the heat passing through can not be observed with the naked eye, so the profile of furan resin sand and resin coated sand was used to observe ablation. The profile of resin coated sand was used to observe the heat passing through. Variation coefficient is the standard deviation divided by the average of the test results. It is used to characterize the reproducibility of the test results. The height of the sample was unified at $30 \mathrm{~mm}$ because a smaller sample size is needed. The diameters of samples used for resin sand high temperature test were mostly between 11 and $25 \mathrm{~mm}$. So the solid sample sizes were selected as $\Phi 12 \times 30 \mathrm{~mm}$, $\Phi 16 \times 30 \mathrm{~mm}$, and $\Phi 20 \times 30 \mathrm{~mm}$. The hollow sample sizes were selected as $\Phi 20 / 5 \times 30 \mathrm{~mm}(\Phi 20 / 5$ means its outer diameter is $20 \mathrm{~mm}$, its inner diameter is $5 \mathrm{~mm}), \Phi 20 / 10 \times 30 \mathrm{~mm}, \Phi 25 / 5 \times 30$ $\mathrm{mm}, \Phi 25 / 10 \times 30 \mathrm{~mm}$, and $\Phi 25 / 15 \times 30 \mathrm{~mm}$. In order to make those eight sizes of samples, two sets of moulds were processed for the sample preparation. A set of iron moulds for coated sand is shown in Fig. 1. A set of wooden moulds for self-hardening furan resin sand is shown in Fig. 2.

The resin sands used were factory-produced, which included a kind of coated sand for cast iron (ZSK140/70), a kind of coated sand for cast non-ferrous alloy (ZSP140/70), a kind of furan
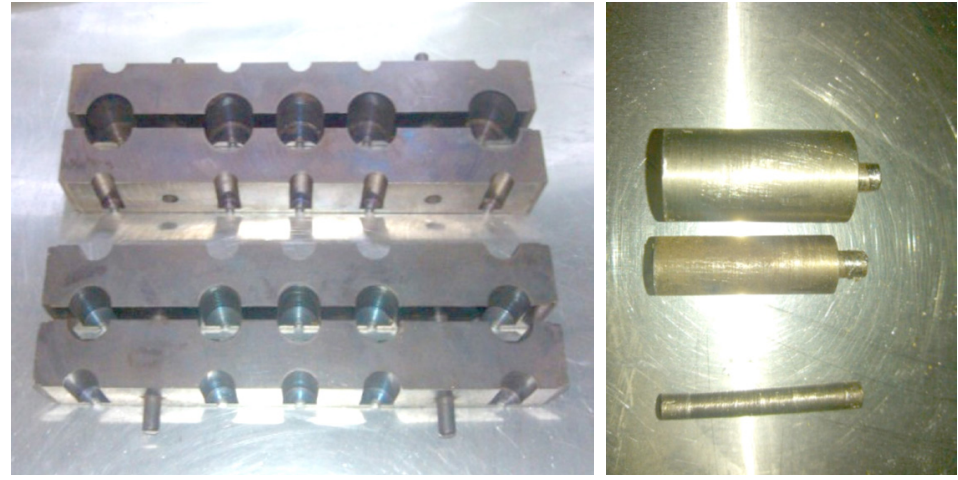

Fig. 1: Iron mould and iron cores

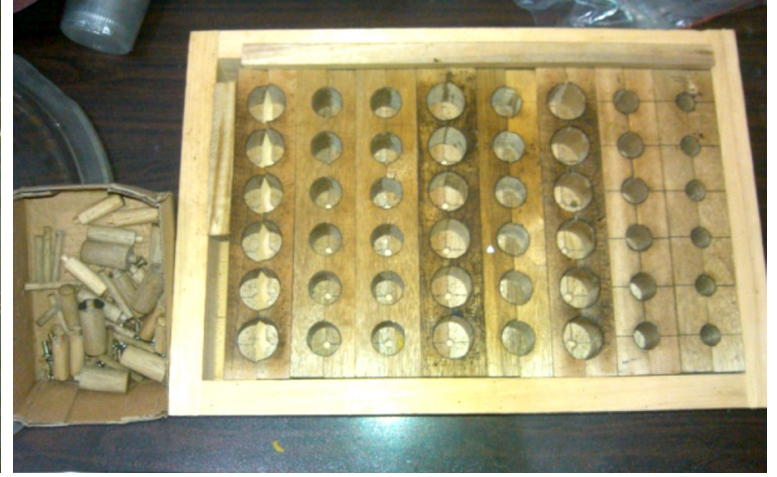

Fig. 2: Wooden mold and wooden cores resin self-setting sand for cast iron (ZFH801) and a kind of furan resin self-setting sand for cast non-ferrous alloy (ZFN702). The original sand was Dalin standard sand.

The heat preservation temperature of the coated sand was $225^{\circ} \mathrm{C}$ and its holding time was $2 \mathrm{~min}$. The high temperature performance was measured after 24 hours. The amount of added resin was $1.5 \%$ of sand, and the amount of added curing agent was $60 \%$ of resin. Sand mixing process was: weighing sand $\rightarrow$ adding curing agent with a glue dropper $\rightarrow$ mixing $\rightarrow$ adding resin with another glue dropper $\rightarrow$ mixing. The sand was put into the wooden mould after the sand mixing. The sand was rammed to fill up the mold. The high temperature performance was measured after 24 hours.

The high temperature compressive strength of the sand sample was tested by a self-developed instrument (Fig. 3). The high temperature compressive strength measuring method is as follows: the sand sample for cast iron was put into the furnace and kept at $1,000{ }^{\circ} \mathrm{C}$ (the coated sand sample for cast nonferrous alloy was kept at $800{ }^{\circ} \mathrm{C}$ ), then the sample was pressed after heat preservation. The maximum strength in the process of measurement is the high temperature compression strength.

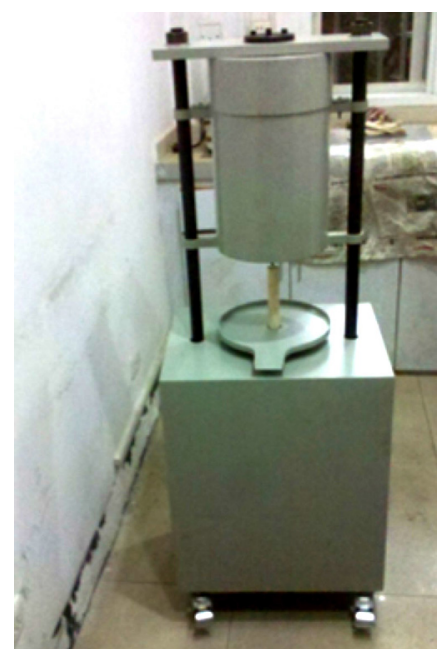

Fig. 3: Instrument for high temperature mechanical properties of resin sand 


\subsection{Heat through and ablation of eight sizes of resin sand samples}

In order to observe the heat through and ablation situation of the resin sand, samples were divided into two parts and placed into the new instrument to measure the high temperature mechanical properties of resin sand. The sample was taken out after a period of holding time and its profile was observed. In order to ensure a reducing atmosphere, a lid was put on the top of the furnace and sealed. The chamber of the furnace was filled with the reducing atmosphere after continuous measurement of five samples.

Considering that the operating temperature of resin sand for cast non-ferrous alloy is lower than the resin sand for cast iron, two kinds of resin sand for cast iron were held for $1 \mathrm{~min}$ at 1,000 ${ }^{\circ} \mathrm{C}$. The heat through and the ablation were observed after the sample was taken out. Two kinds of resin sand for cast nonferrous alloy were held for $1 \mathrm{~min}$ at $800{ }^{\circ} \mathrm{C}$. The heat through and ablation were observed after the sample was taken out. Sample pictures are shown in Table 1.

Table 1: Heat through and ablation of sand sample

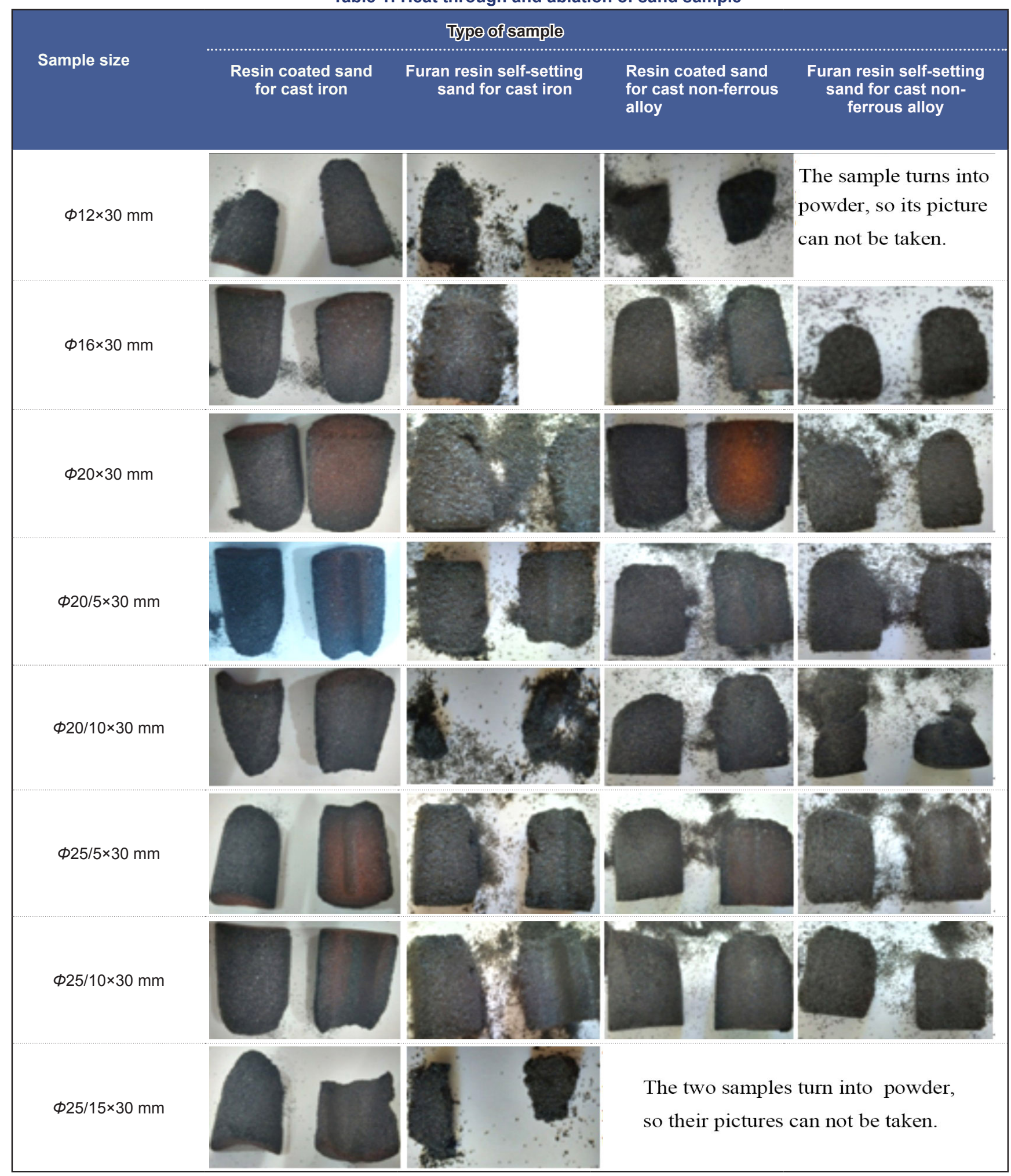


The heat passing through the samples was rated. Figure 4 shows the heat through situation of different samples. The original sample is shown in Fig. 4(a). The sample in which only the surface was heated through (as shown in Fig. 4b) was classified as grade 1. The sample in which the core is not heated through (as shown in Fig. 4c) was classified as grade 2. The sample which is nearly heated through (as shown in Fig. 4d) was classified as grade 3 . The sample which is completely heated through (as shown in Fig. 4e) was classified as grade 4. Samples of grade 1 and grade 2 are not suitable for high temperature performance test due to uneven heat through.
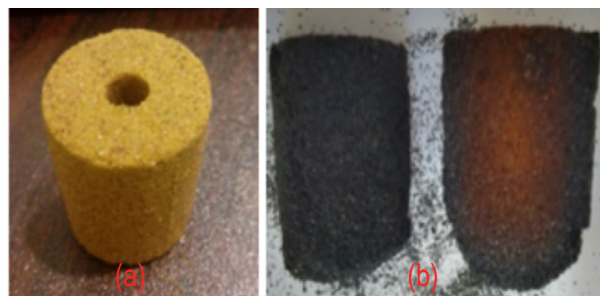
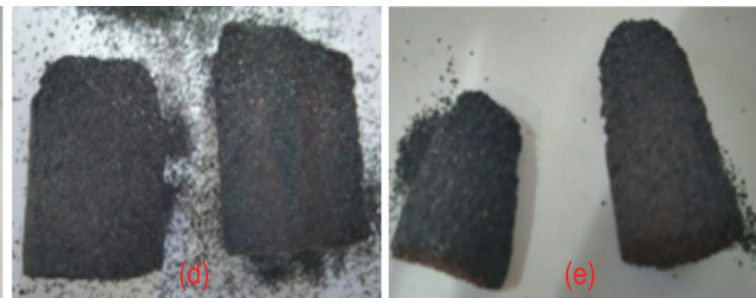

Fig. 4: Heat through contrast

The heat through of 8 kinds of samples were rated, as shown in Table 2. It can be seen from Table 2 that these five sizes of samples $(\Phi 12 \times 30 \mathrm{~mm}, \Phi 16 \times 30 \mathrm{~mm}, \Phi 20 / 5 \times 30 \mathrm{~mm}, \Phi 20 / 10 \times 30$ $\mathrm{mm}$, and $\Phi 25 / 15 \times 30 \mathrm{~mm}$ ) have been completely heated through.

\section{Table 2: Resin sand heat through level}

\begin{tabular}{ccc}
$\begin{array}{c}\text { Sample } \\
\text { size }\end{array}$ & $\begin{array}{c}\text { Resin coated } \\
\text { sand for cast } \\
\text { iron heat } \\
\text { through (level) }\end{array}$ & $\begin{array}{c}\text { Resin coated } \\
\text { sand for cast } \\
\text { non-ferrous alloy } \\
\text { heat through (level) }\end{array}$ \\
\hline $12 \times 30 \mathrm{~mm}$ & 4 & 4 \\
$\Phi 16 \times 30 \mathrm{~mm}$ & 3 & 3 \\
$\Phi 20 \times 30 \mathrm{~mm}$ & 2 & 1 \\
$\Phi 20 / 5 \times 30 \mathrm{~mm}$ & 3 & 3 \\
$\Phi 20 / 10 \times 30 \mathrm{~mm}$ & 4 & 4 \\
$\Phi 25 / 5 \times 30 \mathrm{~mm}$ & 1 & 2 \\
$\Phi 25 / 10 \times 30 \mathrm{~mm}$ & 2 & 3 \\
$\Phi 25 / 15 \times 30 \mathrm{~mm}$ & 4 & 4
\end{tabular}

The ablation of the sample was rated. Figure 5 shows the ablation situation of different samples. The original sample is shown in Fig. 5(a). The sample which is fully broken (Fig. 5b) was classified as grade 1 . The sample which is partially broken (Fig. 5c) was classified as grade 2. The sample which is mostly intact (Fig. 5d) was classified as grade 3. The sample which has remained intact (Fig. 5e) was classified as grade 4. Samples of grade 1 and grade 2 are not suitable for high temperature performance test due to too much ablation.

The ablations of 8 sizes of samples were rated as shown in Table 3. It can be seen from Table 3 that four kinds of sample sizes $(\Phi 16 \times 30 \mathrm{~mm}, \Phi 20 \times 30 \mathrm{~mm}, \Phi 20 / 5 \times 30 \mathrm{~mm}, \Phi 25 / 5 \times 30$ $\mathrm{mm})$ are mostly intact.

In conclusion, $\Phi 16 \times 30 \mathrm{~mm}$ and $\Phi 20 / 5 \times 30 \mathrm{~mm}$ were selected as the sample sizes. They are mostly intact and they have been completely heated through. The optimal thickness of high temperature performance resin sand sample was 7.5-8 $\mathrm{mm}$. There are two kinds of sample from which to choose, so it was necessary to determine which one is more appropriate using the testing procedure that follows.
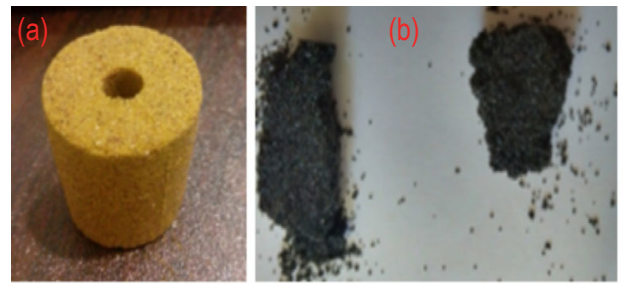

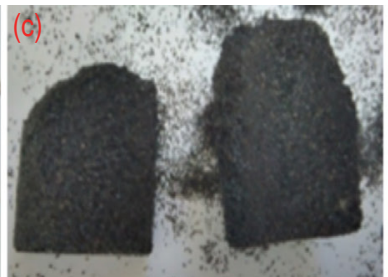

Fig. 5: Ablation of sample
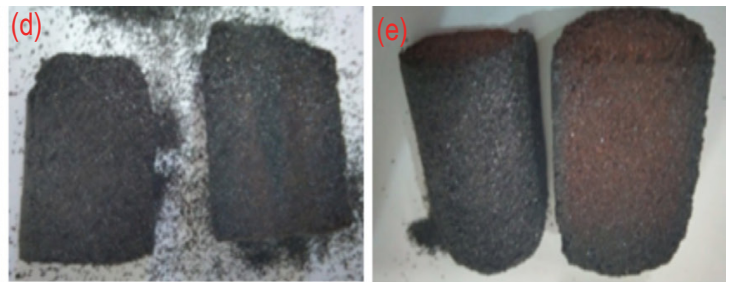

Table 3: Resin sand ablation level

\begin{tabular}{|c|c|c|c|c|}
\hline $\begin{array}{l}\text { Sample } \\
\text { size }\end{array}$ & $\begin{array}{c}\text { Resin coated sand for } \\
\text { cast iron ablation } \\
\text { (level) }\end{array}$ & $\begin{array}{c}\text { Furan resin self-setting } \\
\text { sand for cast iron } \\
\text { ablation (level) }\end{array}$ & $\begin{array}{l}\text { Resin coated sand for } \\
\text { cast non-ferrous alloy } \\
\text { ablation (level) }\end{array}$ & $\begin{array}{c}\text { Furan resin self-setting } \\
\text { sand for cast non-ferrous } \\
\text { alloy ablation (level) }\end{array}$ \\
\hline$\Phi 12 \times 30 \mathrm{~mm}$ & 2 & 2 & 2 & 1 \\
\hline$\Phi 16 \times 30 \mathrm{~mm}$ & 3 & 3 & 3 & 3 \\
\hline$\Phi 20 \times 30 \mathrm{~mm}$ & 4 & 3 & 4 & 3 \\
\hline$\Phi 20 / 5 \times 30 \mathrm{~mm}$ & 3 & 3 & 3 & 3 \\
\hline$\Phi 20 / 10 \times 30 \mathrm{~mm}$ & 2 & 1 & 2 & 2 \\
\hline$\Phi 25 / 5 \times 30 \mathrm{~mm}$ & 3 & 3 & 3 & 3 \\
\hline$\Phi 25 / 10 \times 30 \mathrm{~mm}$ & 3 & 2 & 2 & 2 \\
\hline$\Phi 25 / 15 \times 30 \mathrm{~mm}$ & 2 & 1 & 1 & 1 \\
\hline
\end{tabular}




\subsection{High temperature compressive strength and variation coefficient of two sizes of resin sand}

The size of the resin sand high temperature compressive strength sample was selected through the variation coefficient of the experimental data. Five data were measured and an average was taken as the measuring result as shown in the Tables 4 and 5 .

It can be found from Tables 4 and 5 that the hollow samples can better reflect the difference among different resin sands. It can be observed that the variation coefficient of the $\Phi 16 \times 30 \mathrm{~mm}$ sample is greater. The reason is that it is difficult to heat through the solid sample center. The heating uniformity of the hollow sample is better than that of the solid sample.

Therefore, the $\Phi 20 / 5 \times 30 \mathrm{~mm}$ sample was selected as the standard sample size.

\section{Determination of high temperature compressive strength testing method}

\subsection{Experimental scheme}

High temperature compressive strength is an instant strength of sand mixtures that is measured after a certain time of heat preservation. Therefore, the appropriate heat preservation temperature and the holding time need to be determined.

The preparation of the sample is the same as mentioned above. For the samples kept at 600,800 or $1,000{ }^{\circ} \mathrm{C}$ for $1 \mathrm{~min}$, high temperature compressive strength was measured at different temperatures. For the samples kept at $1,000^{\circ} \mathrm{C}$ for $0.5 \mathrm{~min}, 1$ min or $1.5 \mathrm{~min}$ (resin sand for cast non-ferrous alloy was kept at $800{ }^{\circ} \mathrm{C}$ ), high temperature compressive strength was measured at different holding times. Changes in strength and the variation

Table 4: High temperature compressive strength of $\Phi 16 \times 30 \mathrm{~mm}$ samples and their variation coefficients

\begin{tabular}{|c|c|c|c|}
\hline Type of resin sand & $\begin{array}{l}\text { Heat preservation } \\
\text { temperature } \\
\left({ }^{\circ} \mathrm{C}\right)\end{array}$ & $\begin{array}{l}\text { High temperature } \\
\text { compressive strength of } \\
\Phi 16 \times 30 \mathrm{~mm} \text { sample } \\
(\mathrm{MPa})\end{array}$ & $\begin{array}{l}\text { Variation coefficient of } \\
\text { high temperature } \\
\text { compressive strength of } \\
\Phi 16 \times 30 \mathrm{~mm} \text { sample (\%) }\end{array}$ \\
\hline Resin coated sand for cast iron & 1,000 & 0.19 & 3.0 \\
\hline Furan resin self-setting sand for cast iron & 1,000 & 0.18 & 7.1 \\
\hline Resin coated sand for cast non-ferrous alloy & 800 & 0.39 & 18.0 \\
\hline $\begin{array}{l}\text { Furan resin self-setting sand for cast } \\
\text { non-ferrous alloy }\end{array}$ & 800 & 0.21 & 38.9 \\
\hline
\end{tabular}

Table 5: High temperature compressive strength of $\Phi 20 / 5 \times 30 \mathrm{~mm}$ samples and their variation coefficients

\begin{tabular}{|c|c|c|c|}
\hline Type of resin sand & $\begin{array}{c}\text { Heat preservation } \\
\text { temperature } \\
\left({ }^{\circ} \mathrm{C}\right)\end{array}$ & $\begin{array}{c}\text { High temperature compressive } \\
\text { strength of } \Phi 20 / 5 \times 30 \mathrm{~mm} \\
\text { sample }(\mathrm{MPa})\end{array}$ & $\begin{array}{l}\text { Variation coefficient of high } \\
\text { temperature compressive } \\
\text { strength of } \Phi 20 / 5 \times 30 \mathrm{~mm} \\
\text { sample (\%) }\end{array}$ \\
\hline Resin coated sand for cast iron & 1,000 & 0.20 & 9.8 \\
\hline Furan resin self-setting sand for cast iron & 1,000 & 0.12 & 9.2 \\
\hline Resin coated sand for cast non-ferrous alloy & 800 & 0.41 & 8.9 \\
\hline $\begin{array}{l}\text { Furan resin self-setting sand for cast non- } \\
\text { ferrous alloy }\end{array}$ & 800 & 0.16 & 5.7 \\
\hline
\end{tabular}

coefficient of the experimental data were analyzed in order to select the appropriate measurement parameters of resin sand high temperature compressive strength.

\subsection{Results and analysis}

Table 6 shows the results of high temperature compressive strength for samples kept at 600,800 or $1,000{ }^{\circ} \mathrm{C}$ for $1 \mathrm{~min}$. Table 7 shows the results of high temperature compressive strength for samples kept at $1,000{ }^{\circ} \mathrm{C}$ for $0.5 \mathrm{~min}$ and $1 \mathrm{~min}$ (resin sand for cast non-ferrous alloy was at $800^{\circ} \mathrm{C}$ ). The strength of the sample under the condition of $1.5 \mathrm{~min}$ was too low, and its data was very unstable, therefore the data was not shown in Table 7.

It can be found from Table 6 that the high temperature compressive strength of coated sand is higher than furan resin sand, and the high temperature compressive strength of resin sand for cast iron is higher than resin sand for cast non-ferrous alloy. The variation coefficient of measurement results under $600{ }^{\circ} \mathrm{C}$ is greater than $10 \%$, it doesn't fit the measurement criteria. The variation coefficients of measurement results of resin sand for cast non-ferrous alloy under $800{ }^{\circ} \mathrm{C}$ are less than $10 \%$, but the variation coefficients of measurement results of furan resin self-setting sand for cast iron under $800{ }^{\circ} \mathrm{C}$ are not less than $10 \%$. The variation coefficients of measurement results under $1,000{ }^{\circ} \mathrm{C}$ are less than $10 \%$. Therefore, the optimal test temperature for resin sand for cast non-ferrous alloy is $800{ }^{\circ} \mathrm{C}$ and the optimal test temperature for resin sand for cast iron is $1,000^{\circ} \mathrm{C}$.

It can be found from Table 7 that $0.5 \mathrm{~min}$ samples have not been fully heated through. The variation coefficients of $1 \mathrm{~min}$ measurement results are less than those of 0.5 min measurement results. Therefore, $1 \mathrm{~min}$ was selected as the holding time for resin sand high temperature compressive strength.

The high temperature compressive strength measuring method was finally determined as follows: the $\Phi 20 / 5 \times 30 \mathrm{~mm}$ sand sample was put into the furnace and kept at $1,000{ }^{\circ} \mathrm{C}$ for 1 $\min$ (the coated sand sample for cast non-ferrous alloy or other resin sand which has very low high temperature strength was kept at $800^{\circ} \mathrm{C}$ ); the sample was pressed after heat preservation. The maximum strength in the process of measurement is the 
Table 6: High temperature compressive strength of four kinds of resin sand under different temperatures

\begin{tabular}{|c|c|c|c|}
\hline Type of resin sand & $\begin{array}{l}\text { Heat preservation } \\
\text { temperature }\left({ }^{\circ} \mathrm{C}\right)\end{array}$ & $\begin{array}{l}\text { High temperature compressive } \\
\text { strength (MPa) }\end{array}$ & $\begin{array}{c}\text { Variation coefficient of high } \\
\text { temperature compressive } \\
\text { strength (\%) }\end{array}$ \\
\hline \multirow{3}{*}{ Resin coated sand for cast iron } & 600 & 1.14 & 12.4 \\
\hline & 800 & 0.46 & 4.4 \\
\hline & 1,000 & 0.20 & 9.8 \\
\hline \multirow{3}{*}{ Furan resin self-setting sand for cast iron } & 600 & 1.12 & 17.7 \\
\hline & 800 & 0.16 & 11.4 \\
\hline & 1,000 & 0.12 & 9.2 \\
\hline \multirow{3}{*}{$\begin{array}{l}\text { Resin coated sand for cast non-ferrous } \\
\text { alloy }\end{array}$} & 600 & 1.12 & 10.3 \\
\hline & 800 & 0.39 & 8.9 \\
\hline & 1,000 & 0.23 & 7.6 \\
\hline \multirow{3}{*}{$\begin{array}{l}\text { Furan resin self-setting sand for cast non- } \\
\text { ferrous alloy }\end{array}$} & 600 & 0.93 & 14.0 \\
\hline & 800 & 0.21 & 5.7 \\
\hline & 1000 & 0.16 & 6.7 \\
\hline
\end{tabular}

Table 7: High temperature compressive strength under different preservation times

\begin{tabular}{|cccc|}
\hline Type of resin sand & $\begin{array}{c}\text { Heat preservation } \\
\text { time }(\mathrm{min})\end{array}$ & $\begin{array}{c}\text { High temperature compressive } \\
\text { strength (MPa) }\end{array}$ & $\begin{array}{c}\text { Variation coefficient of high } \\
\text { temperature compressive } \\
\text { strength }(\%)\end{array}$ \\
\hline Resin coated sand for cast iron & 0.5 & 0.50 & 9.2 \\
Furan resin self-setting sand for cast iron & 1 & 0.20 & 9.8 \\
Resin coated sand for cast non-ferrous & 0.5 & 0.28 & 17.3 \\
$\quad$ alloy & 0.5 & 0.12 & 9.2 \\
\hline Furan resin self-setting sand for cast non- & 1 & 0.78 & 6.1 \\
ferrous alloy & 0.5 & 0.39 & 8.9 \\
\hline
\end{tabular}

high temperature compressive strength.

\section{High temperature compressive strength test results of different resin sands}

In order to verify whether the testing method can truthfully reflect the high temperature performance of resin sand, the high temperature compressive strength of different kinds of resin sand and the effects of different resin added amounts on the high temperature compressive strength were tested.

Table 8 shows the high temperature performance of different kinds of resin sand. $1 \#$ is coated sand for cast iron. $2 \#$ is special coated sand. $3 \#$ is ceramsite resin coated sand. $4 \#$ is furan resin self-setting sand for cast iron (base sand is Dalin standard sand, resin added amount is $1.5 \%$ ). $5 \#$ is TEA resin sand. $6 \#$ is furan resin self-setting sand for cast iron (base sand is Dalin standard sand, resin added amount is $1 \%$ ). $7 \#$ is furan resin self-setting sand for cast iron (base sand is Dalin standard sand, resin added amount is $1.25 \%$ ). $8 \#$ is furan resin self-setting sand for cast iron (base sand is Dalin standard sand, resin added amount is
1.75\%). 9\# is furan resin self-setting sand for cast iron (base sand is Dalin standard sand, resin added amount is $2 \%$ ). The preparations of sample, test and data analysis are the same as above (TEA resin was put into the furnace and kept at $800{ }^{\circ} \mathrm{C}$ for 1 min because of its low high temperature strength), and the measurement results are shown in Table 8 and Figs. 6 and 7 .

It can be seen from $1 \#$ to $5 \#$ that phenol-formaldehyde resin coated sand has a higher high temperature compressive strength. Both TEA resin sand and furan resin self-setting sand have a lower high temperature compressive strength. Both special coated sand and ceramsite resin coated sand have a higher high temperature compressive strength than ordinary coated sand. The experimental results are in conformity with the several kinds of resin sand used at high temperature. Phenol-formaldehyde resin coated sand has a higher strength at high temperature. The base sand of special coated sand ${ }^{[9]}$ and ceramsite resin coated sand are special ${ }^{[10]}$; they have better high temperature properties than ordinary coated sand.

It can be found from $4 \#, 6 \#, 7 \#, 8 \#$ and $9 \#$ that the high temperature compressive strength of furan resin self-setting sand increases with the resin added amount; the higher the resin added amount, the higher its strength at room temperature. Thus 
Table 8: Temperature compressive strength of different resin sands

\begin{tabular}{ccc} 
Type of sand & $\begin{array}{c}\text { High temperature } \\
\text { compressive } \\
\text { strength (MPa) }\end{array}$ & $\begin{array}{c}\text { Variation coefficient of } \\
\text { high temperature } \\
\text { compressive strength } \\
\text { (\%) }\end{array}$ \\
1\# & 0.20 & 9.8 \\
$2 \#$ & 0.37 & 9.3 \\
$3 \#$ & 0.26 & 9.6 \\
$4 \#$ & 0.12 & 9.2 \\
$5 \#$ & 0.10 & 3.0 \\
$6 \#$ & 0.09 & 6.2 \\
$7 \#$ & 0.11 & 8.6 \\
$8 \#$ & 0.13 & 3.8 \\
$9 \#$ & 0.13 & 9.6 \\
\hline
\end{tabular}

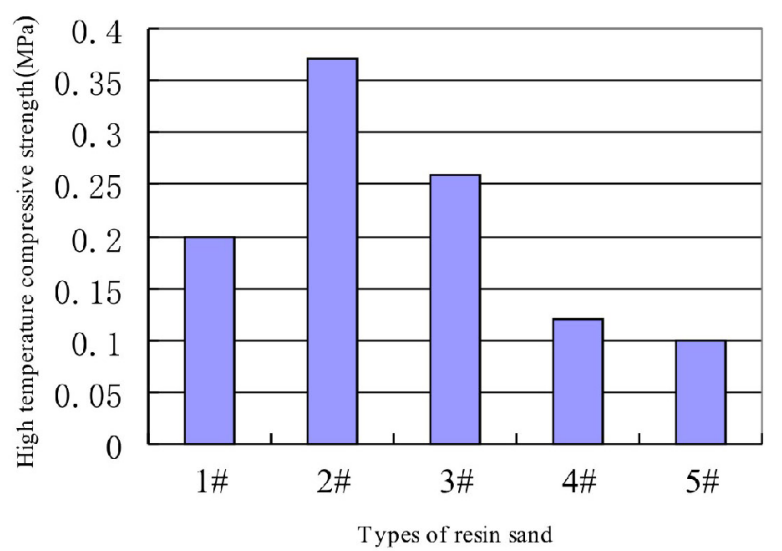

Fig. 6: High temperature compressive strength of different resin sands

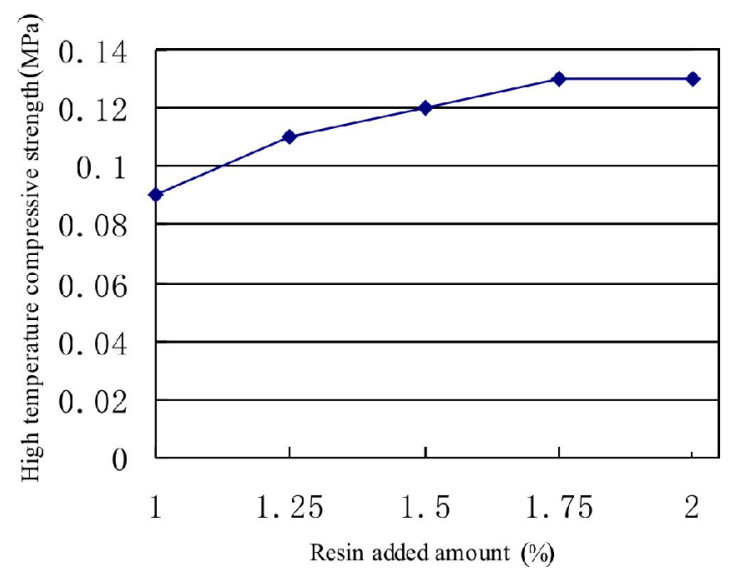

Fig. 7: Effects of different resin added amounts on high temperature compressive strength

the number of its bond bridge at high temperature is greater too, so its high temperature compressive strength value is greater. This is consistent with the actual situation.

This testing method can truthfully reflect the high temperature performance of resin sand. The variation coefficient of phenolformaldehyde resin coated sand, furan resin self-setting sand and TEA resin sand is under $10 \%$. Therefore, it can truthfully reflect the high temperature performance of three kinds of resin sand.

\section{Conclusions}

(1) The optimal wall thickness of the resin sand sample is 7.5$8 \mathrm{~mm}$, a hollow cylinder sample can reflect the strength difference of different resin sands better than the solid cylinder sample, and its data is stable. The appropriate hollow sample size is $\Phi 20 / 5 \times 30$ $\mathrm{mm}$.

(2) For the resin sand for cast steel and cast iron, $1,000{ }^{\circ} \mathrm{C}$ is the optimal test temperature of high temperature compressive strength; for the resin sand for cast non-ferrous alloy, $800{ }^{\circ} \mathrm{C}$ is the optimal test temperature, and the holding time of $1 \mathrm{~min}$ is the best.

(3) This testing method can truthfully reflect the high temperature performance of resin sand. The variation coefficients of phenol-formaldehyde resin coated sand, furan resin self-setting sand, and TEA resin sand are under $10 \%$.

\section{References}

[1] Wang Wenqing, Luo Jirong, Ye Shenping, et al. Research on high temperature performance test technology of resin sand. In: Proceedings of the National Symposium of Casting Process Control Technology, 1987. (In Chinese)

[2] Wan Peng, Li Yuancai, Ling Hongjiang, et al. Present status and development of molding sand high temperature test and its apparatus. Foundry Equipment and Technology, 2014, (1): 7-12. (In Chinese)

[3] Des Plaines Illinois. Foundry Sand Handbook. The American Foundrymen Society, 1963

[4] Ran Lina, Sun Xushen, Zu Xian, et al. High temperature test and practical application of core sand. In: Proceedings of the 10th China Foundry Association Annual Meeting, 2012. (In Chinese)

[5] Wu Jian. Attention to sand high temperature performance testing must be paid in order to improve the quality of the casting. Physical Testing and Chemical Analysis, 1993, 29(1): 64. (In Chinese)

[6] Dobosz S M, Jelinek P, Major-Gabry K. Development tendencies of moulding and core sands. China Foundry, 2011, 8(04): 438-446.

[7] Shao Jingcheng, Wu Min, Ai Guo, et al. Effects of Oxidants on Collapsibility of Resin Bonded Sand. Foundry, 2011, 60(01): 70-72. (In Chinese)

[8] Zhou Zaili, Shi Xiaoyang, Zhang Xuguo, et al. Determination of the High Temperature Properties of Coated Sand. Foundry Technology, 2011 (8): 1064-1066. (In Chinese)

[9] Liu Xiangdong, Xiao Kezhe, and Wang Wenqing. Thermal Expansion Properties Comparison between Coated Special Sand and Coated Silica Sand. Modern Cast Iron, 1999 (4): 1316. (In Chinese)

[10] Liu Yue, Xing Wating, Zhen Xiaopin et al. Green and environmentally friendly foundry materials - Application status and prospects of ceramsite sand in foundry production. In: Proceedings of 2015 China Foundry Week, 2015. (In Chinese) 